\title{
Long-term trends in mesozooplankton abundance in Chesapeake Bay, USA: influence of freshwater input
}

\author{
David G. Kimmel* ${ }^{*}$ Michael R. Roman
}

Horn Point Laboratory, University of Maryland Center for Environmental Science, PO Box 775, Cambridge, Maryland 21613, USA

\begin{abstract}
Analyses of a 16 year time-series (1985-2000) of mesozooplankton abundance in the Chesapeake Bay reveal the influence of freshwater flow on species composition and abundance. Trend analysis and linear mixed-effects regression models were used to assess long-term variation in, and influence of water-quality parameters (modulated by freshwater input) on, the monthly mean abundance of the 2 dominant copepod species Acartia tonsa and Eurytemora affinis. There were no long-term trends in abundance of either copepod species, with the exception of a slight downward trend for A. tonsa in the mesohaline region of the northern Chesapeake Bay. There were no longterm trends in temperature, but there was a downward trend in salinity related to a wet period in the late 1990s. Linear mixed-effects models showed a negative correlation between freshwater input and A. tonsa abundance in the oligohaline region, and no significant relationship between other waterquality parameters and $A$. tonsa abundance in the mesohaline region. A. tonsa abundance was positively correlated with temperature in the polyhaline region. E. affinis abundance in the oligohaline region was negatively correlated with biovolume of the ctenophore Mnemiopsis leidyi and positively correlated with phytoplankton abundance. A negative correlation with salinity and a positive correlation with turbidity were found for $E$. affinis in the mesohaline region. While years of above-average freshwater input were characterized in the spring by high abundances of $E$. affinis in the mesohaline region and low abundances of $A$. tonsa in the oligohaline region, the former may show a lagged response depending on the time and magnitude of the input. Freshwater input appears to be mainly influencing habitat parameters specific to each copepod species and top-down control by predators.
\end{abstract}

KEY WORDS: Freshwater input · Acartia tonsa · Eurytemora affinis · Estuary · Trend analysis · Linear mixed-effects model

\section{INTRODUCTION}

The Susquehanna and Potomac Rivers account for approximately 50 and $16 \%$, respectively, of the overall freshwater discharge into the Chesapeake Bay (Schubel \& Pritchard 1986). The rivers deliver nutrients and suspended material to the Bay, with peak flows usually occurring during the spring. Freshwater input influences both timing and magnitude of the spring phytoplankton bloom in the Chesapeake Bay (Malone et al. 1988) and in other estuarine systems (Mallin et al. 1993, Jassby \& Powell 1994). Changes in freshwater discharge stimulate estuarine primary production (Flint 1985), cause major trophic shifts (Livingston et al. 1997) and influence the abundance of estuarine organisms (Kimmerer 2002). However, the influence of freshwater input on the mesozooplankton community in the Chesapeake Bay has not been rigorously assessed. Mesozooplankton (200 $\mu \mathrm{m}$ to $2 \mathrm{~mm}$; Sieburth et al. 1978) play an important role in linking estuarine primary production to fish production. The Chesapeake Bay mesozooplankton community is dominated by 2 calanoid copepod species, Acartia tonsa and Eurytemora affinis (Brownlee \& Jacobs 1987). We hypothesize that the timing and magnitude of freshwater input is an important factor influencing the distribution and abundance of these 2 species in the Chesapeake Bay. We predict that freshwater input alters both bottom-up 
and top-down pathways that influence the abundance of A. tonsa and E. affinis. Thus, physical forcing of habitat changes and trophic linkages are both important factors modulated by freshwater input.

The Chesapeake Bay Program (CBP) has been monitoring mesozooplankton abundance in Chesapeake Bay since August 1984. Recently, it was reported that summer abundances of mesozooplankton were declining in the mesohaline region of the Bay, and mesozooplankton species diversity was decreasing in many tributaries and in the main stem of the northern Chesapeake Bay (Workshop on Trophic Change in Chesapeake Bay Open Water Habitat 1998).

In order to assess the status of mesozooplankton in the main stem Chesapeake Bay, we examined longterm trends in Acartia tonsa and Eurytemora affinis abundance. Our goal was to examine the spatial, seasonal and interannual variability for each copepod species in relation to variation in freshwater flow into the Bay. During the past $16 \mathrm{yr}$, mean annual freshwater input into the entire Bay has shown considerable variability (Fig. 1). Thus, a natural experiment has occurred over the time-series allowing us to assess the impacts of 'wet' and 'dry' periods on mesozooplankton abundance and community composition.

We addressed the following questions: Is there a relationship between hydrologic conditions and mesozooplankton abundance and community composition? If such a relationship exists, is it possible to relate mesozooplankton abundance and composition to water-quality and biological variables in order to

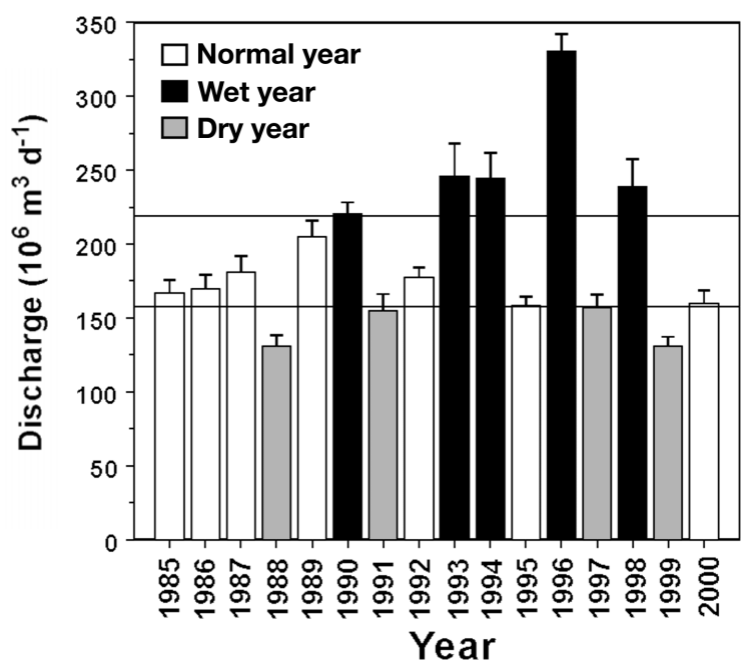

Fig. 1. Yearly mean freshwater discharge $\left(10^{6} \mathrm{~m}^{3} \mathrm{~d}^{-1}\right)$ into the Chesapeake Bay. Bounded region at center of graph represents the median range (1st to 3rd quantile) of freshwater discharge values. Yearly discharges above the 3rd quantile are considered wet years and discharges below the 1st quantile are considered dry years. Error bars represent SE determine variables influencing copepod abundance? Answers to these questions will allow investigators to make inferences about how estuarine mesozooplankton communities will respond to hydrologic changes and how these impacts may affect other trophic levels (Aleem 1972, Montagna \& Kalke 1992).

\section{MATERIALS AND METHODS}

Data collection. Mesozooplankton abundance and water quality data spanning 16 yr (1985 to 2000) were acquired from the CBP (CBP 2000, also available at www.chesapeakebay.net). Mesozooplankton were collected by oblique 5 min tows using $202 \mu \mathrm{m}$ bongo nets that sampled the entire water column. Samples were enumerated (number $\mathrm{m}^{-3}$ ) and identified to species and developmental stage. Maryland (MD) and Virginia (VA) used different enumeration methods to calculate mesozooplankton abundance (CBP 2000, ICPRB 2000). As a result, the VA data contains underestimates of the abundance of smaller species (e.g. Bosmina spp.) and narrow species (e.g. Acartia spp. copepodites; CBP 2000, ICPRB 2000). The VA mesozooplankton data used in our analyses must be considered an approximate abundance estimate only and, because of the loss of smaller species, it was not possible to compare relative abundance of Acartia tonsa and Eurytemora affinis at the VA stations. However, the 'data provide a meaningful status and trend assessments within each state' (ICPRB 2000) and are used in this capacity in our study.

Water-quality data consisted of several parameters: salinity, water temperature $\left({ }^{\circ} \mathrm{C}\right)$, Secchi depth $(\mathrm{m})$, chlorophyll a ( $\left.\mathrm{chl} a, \mu \mathrm{g} \mathrm{l}^{-1}\right)$, total suspended solids (TSS, mg l $\mathrm{l}^{-1}$ ), dissolved oxygen $\left(\mathrm{DO} \mathrm{mg} \mathrm{l}^{-1}\right)$, total nitrogen (TN, mg $\mathrm{l}^{-1}$ as $\mathrm{N}$ ), total phosphorus (TP, $\mathrm{mg} \mathrm{l}^{-1}$ as $\mathrm{P})$ and soluble silica $\left(\mathrm{Si}_{1} \mathrm{mg} \mathrm{l}^{-1}\right)$. Measures of pri-

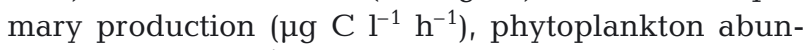
dance (number $\mathrm{l}^{-1}$ ), microzooplankton $(20$ to $200 \mu \mathrm{m}$; Sieburth et al. 1978) abundance (number $\mathrm{l}^{-1}$ ) and the ctenophore Mnemiopsis leidyi biovolume $\left(\mathrm{ml} \mathrm{m}^{-3}\right)$ were also included in the analysis. Methods and equipment used to measure some variables have changed over time. A detailed description of collection and analysis procedures for all CBP data may be found at http://www.chesapeakebay.net/data/index.htm (CBP 2000). The analysis was conducted on data representing 8 stations (Table 1) in the main stem of the Chesapeake Bay (Fig. 2). These stations ranged from oligohaline (0.5 to 5.0 PSU), through mesohaline (5.0 to 18.0 PSU) to polyhaline (>18.0 PSU). Susquehanna River discharge was measured at the Conowingo Dam gauging station and data were acquired from the United States Geological Survey (www.usgs.gov). 
Table 1. General characteristics for each CBP (Chesapeake Bay Progam) sampling station. Regions: I, $36.96-37.40^{\circ} \mathrm{N}$; II, $37.41-37.80^{\circ} \mathrm{N}$; III, $37.81-38.40^{\circ} \mathrm{N}$; IV， $38.41-38.80^{\circ} \mathrm{N}$; $\mathrm{V}, 38.81-39.10^{\circ} \mathrm{N} ; \mathrm{VI}, 39.11-39.66^{\circ} \mathrm{N}$ (Harding \& Perry 1997)

\begin{tabular}{|lcclc|}
\hline Stn & $\begin{array}{c}\text { Latitude } \\
\left({ }^{\circ} \mathrm{N}\right)\end{array}$ & $\begin{array}{c}\text { Longitude } \\
\left({ }^{\circ} \mathrm{W}\right)\end{array}$ & $\begin{array}{l}\text { Salinity } \\
\text { region }\end{array}$ & Region \\
\hline CB2.2 & 39.347 & 76.175 & Oligohaline & VI \\
CB3.3C & 38.996 & 76.360 & Mesohaline & V \\
CB4.3C & 38.556 & 76.435 & Mesohaline & IV \\
CB5.2 & 38.137 & 76.228 & Mesohaline & III \\
CB6.1 & 37.558 & 76.162 & Polyhaline & II \\
CB6.4 & 37.236 & 76.208 & Polyhaline & I \\
CB7.3E & 37.229 & 76.054 & Polyhaline & I \\
CB7.4 & 36.993 & 76.011 & Polyhaline & I \\
\hline
\end{tabular}

Overall freshwater input into the Chesapeake Bay was taken from United States Geological Survey estimates (Bue 1968).

Data analysis. A mean monthly value for each waterquality parameter was calculated by combining the surface (approx. $1 \mathrm{~m}$ ) and bottom (approx. $1 \mathrm{~m}$ above the bottom) water column measurements. This was done because mesozooplankton collections were oblique tows of the whole water column. The CBP cruises typically sampled mesozooplankton and water quality once per month. However, there were periods when sampling was conducted on a biweekly basis or not at all. Periods that are under-represented in the data set are primarily the winter months (Dec, Jan and Feb) in the latter years of the data set. Monthly arithmetic averages were taken for all water-quality variables. There were gaps in the time-series when monthly cruises were not conducted. The monthly arithmetic mean was taken for all mesozooplankton species regardless of life stage, thus the mesozooplankton represented the overall monthly mean abundance for each taxa. Data were transformed where appropriate to ensure normality. The Box-Cox equations were used to select an appropriate transformation for all water-quality parameters (Sokal \& Rohlf 1995). Mesozooplankton (adults and copepodites) data were $\log _{10}(x+1)$ transformed to retain zero values. Some water-quality parameters contained censored values. A censored value occurs when a measurement is below the detection limit of an instrument and is reported as a less than $(<)$ value. The majority of waterquality parameters measured in the northern Chesapeake Bay had less than $2 \%$ of the values censored (e.g. DO $=0.12 \%$, chl $a=1.37 \%, \mathrm{TSS}=1.5 \%, \mathrm{TP}=$ $1.68 \%, \mathrm{Si}=1.4 \%$ ). Total nitrogen had the highest percentage of censored values $(6.7 \%)$. In order to account for censored values, the value representing the limit of detection was used in the analysis.
Mesozooplankton and water-quality data were grouped by month and by sampling station. Analysis of variance was used to examine spatial (station) and temporal (season and year) variation in Acartia tonsa and Eurytemora affinis abundance. Trend estimations were conducted on the mean monthly abundance for $A$. tonsa and E. affinis using the seasonal Kendall test for trend. This test was conducted on non-transformed abundance data to remove seasonal effects on the trend estimation. The seasonal patterns of abundance of A. tonsa and E. affinis were shown by calculating the mean monthly abundance for each species using data from the 4 upper Bay stations (CB2.2, CB3.3C, CB4.3C and CB5.2). Seasonal Kendall trend tests were also conducted on the 16 yr time-series of salinity and temperature. Species composition was examined by taking the yearly arithmetic mean for the dominant $(95 \%$ by abundance) mesozooplankton species found at each station. Due to the large amount of inter-correlation among water-quality parameters, principal components (PC) analysis was conducted on water-quality parameters at each station. The PC analysis produced a new set of linearly recombined variables and reduced the number of variables used in regression models. PCs were produced using a correlation matrix of the

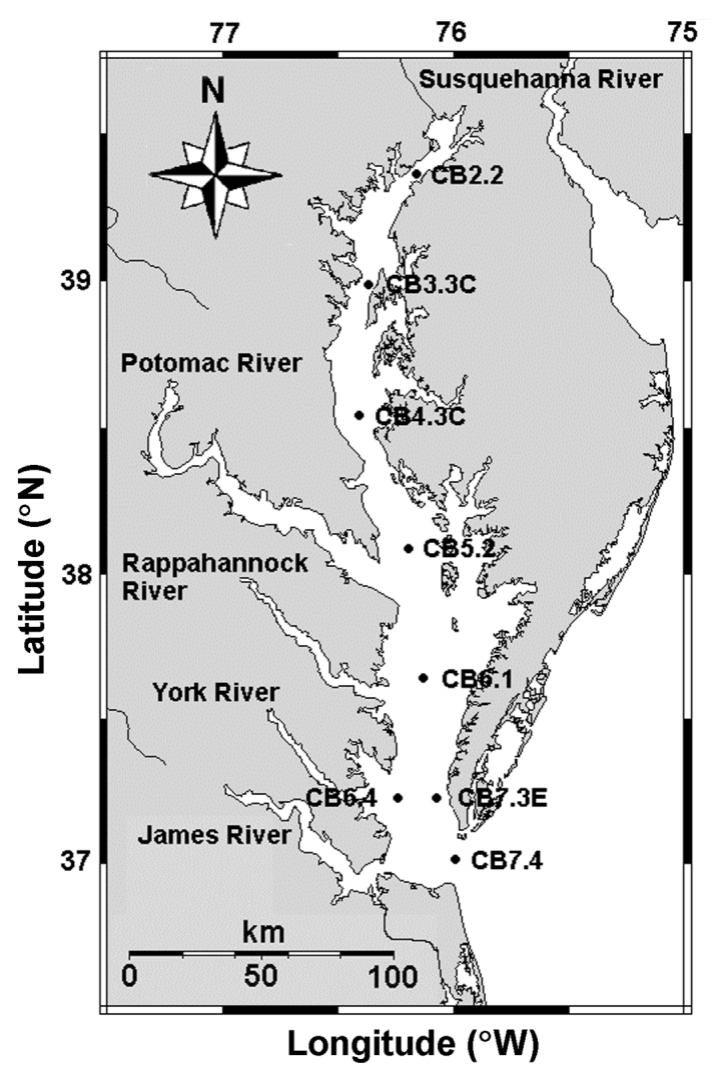

Fig. 2. Chesapeake Bay, showing locations of the Chesapeake Bay Program sampling stations 
Susquehanna River flow (Stns CB2.2, CB3.3C, CB4.3C and CB5.2) or whole Bay freshwater input (Stns CB6.1, CB6.4, CB7.3E and CB7.4), salinity, water temperature, Secchi depth, TSS, DO, TN, TP and Si. PCs with eigenvalues $>1$ were retained for use in the models.

Monthly Eurytemora affinis and Acartia tonsa abundance was modeled using linear mixed-effects models. Linear mixed-effects models are linear regression models used to assess grouped data (Pinheiro \& Bates 2000). Mixed-effects models combine the fixed-effects (repeated levels of experimental factors or groups) and random-effects (Pinheiro \& Bates 2000). Here, the data consisted of repeated monthly measures made at several fixed locations. The use of individual station data in the models allowed us to fix the effect of time in the model. The mixed-effects analysis was used because it reduces serial correlation present in the data, a common feature of time-series. In order to assess the level of serial correlation present in the data after model fitting, the residuals from all linear mixedeffects models were tested for serial correlation using the Rank von Neumann test (Venables \& Ripley 1999).

The predictor variables in the model for the MD stations (CB2.2, CB3.3C, CB4.3C, CB5.2) were the waterquality $\mathrm{PCs}, \mathrm{chl} a$, primary production, phytoplankton abundance, microzooplankton abundance and biovolume of the ctenophore Mnemiopsis leidyi. The predictor variables used for the VA stations (CB6.1, CB6.4, CB7.3E, CB7.4) were the water-quality PCs and chl $a$. Partial or incomplete time-series for similar parameters measured in MD were excluded from the analysis in VA. All parameters were estimated using restricted maximum likelihood and treated as random with month (representing time) as the grouping term in the model. All models were constructed using S-PLUS 6.0 statistical analysis software (Insightful). In order to assess model output during 1995 to 2000, mesozooplankton abundance data collected in April, July and October during the University of Maryland's Land Margin Ecosystem Research (LMER): Trophic Interaction in Estuarine Systems (TIES) project were used. The TIES data were collected along axial and lateral transects of the Chesapeake Bay and thus did not correspond directly to the $\mathrm{CBP}$ monitoring stations used to construct the models. In order to compare the 2 sets of data, the TIES data were divided into 1 of 6 Chesapeake Bay regions based on latitude after (Harding \& Perry 1997) and the arithmetic mean abundance was calculated for each region by month. These values were then compared to the linear mixed-effects model output using a simple linear regression and the calculation of root mean square error (RMSE):

$$
\left[N^{-1} \sum_{i=1}^{N}\left(P_{i}-O_{i}\right)^{2}\right]^{0.5}
$$

where $P_{i}$ is the model predicted value and $O_{i}$ is the observed TIES value.

\section{RESULTS}

\section{Analysis of variance}

Significant variation in Acartia tonsa could be explained by space and time, as well as interactions (ANOVA). The lowest variability appears to be in the mesohaline region and the most variability in the oligohaline and polyhaline regions (Fig. 3). The analysis of variance showed that significant interannual variability was present for $A$. tonsa abundance (Fig. 3).
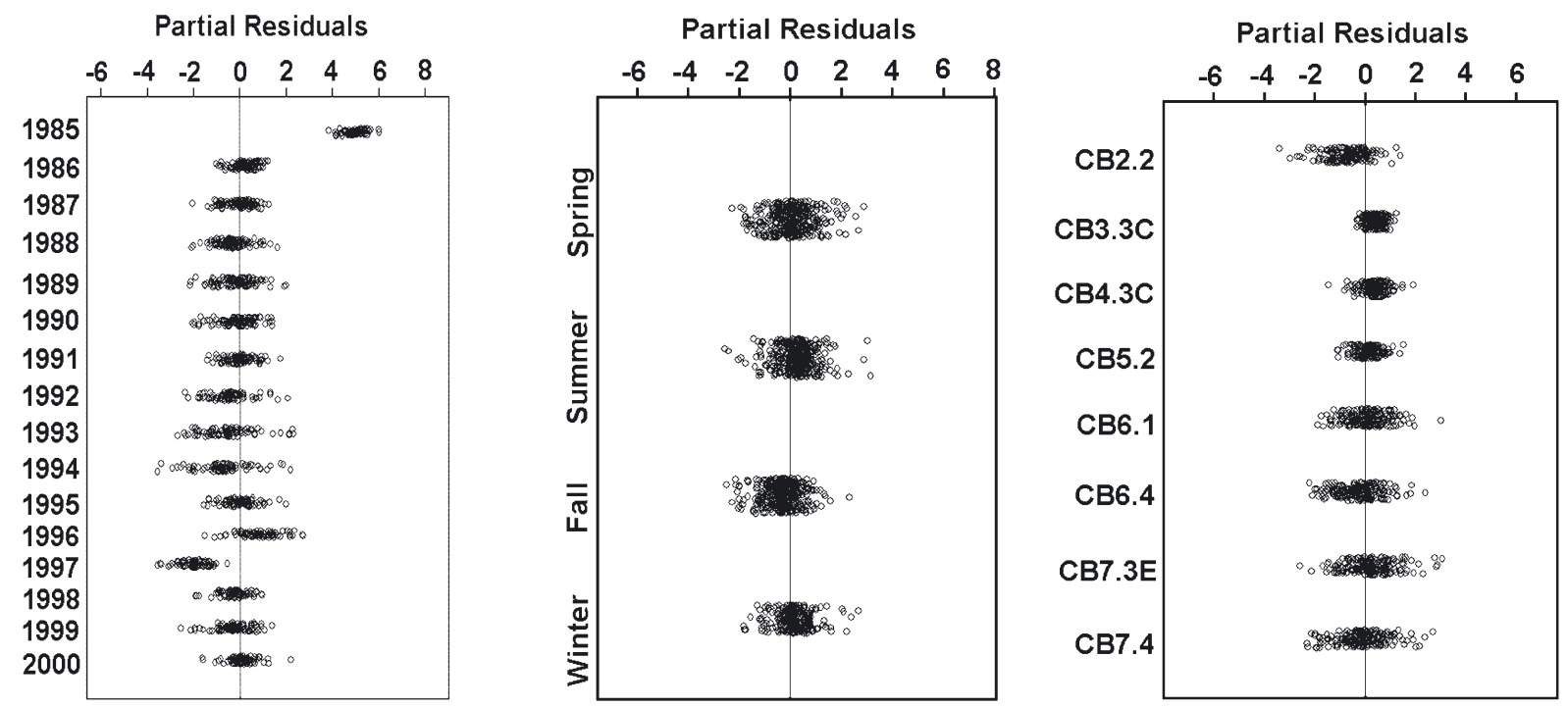

Fig. 3. Partial residuals for station, season and year from ANOVA for Acartia tonsa abundance 

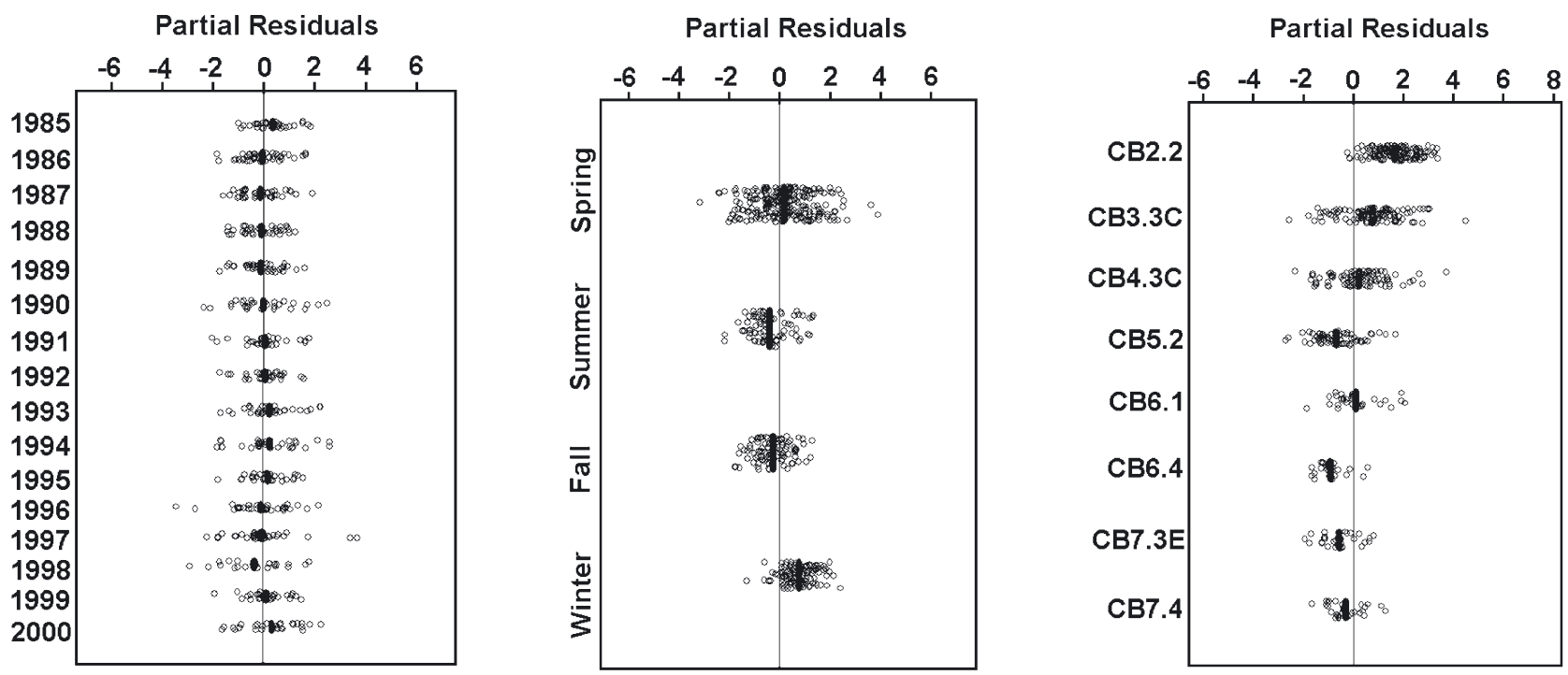

Fig. 4. Partial residuals for station, season and year from ANOVA for Eurytemora affinis abundance

Positive residuals in 1985, negative residuals in 1997 and a period of high variability in abundance during were seen 1993-1994 (Fig. 3). Variation in space and time for Eurytemora affinis abundance was primarily a function of station and season, though year effects were significant (ANOVA). Variation in the abundance of $E$. affinis differed spatially with the highest abundances in the oligohaline and mesohaline regions, and little or no variation in abundance in the polyhaline region (Fig. 4). E. affinis is not commonly found in high salinity waters, so the low variability in this region reflects low abundance measurements. E. affinis showed the highest variability in the winter-spring period and lowest during summer-fall (Fig. 4). The interannual variation in E. affinis abundance showed less fluctuation than $A$. tonsa. The highest interannual variation for $E$. affinis occurred during several periods: 1990, 1993 to 1994 and 1996 to 1998 (Fig. 4); all years of elevated freshwater input or years immediately after a high-flow year (Fig. 1).

\section{Trend analysis and relative abundance patterns}

The seasonal Kendall test for trend revealed no trends in long-term abundance, with the exception of Acartia tonsa at Stn CB5.2 (data not shown) which had a slight downward trend that may have been influenced by the lack of data during 1996 and 1997. The seasonal Kendall test for trend did not reveal any longterm trends in water temperature at any stations. A long-term, downward trend was found for salinity at 6 of the 8 stations (CB4.3, CB5.2, CB6.1, CB6.4, CB7.3E, CB7.4; $<$ 0.05). Mean monthly abundances of $A$. tonsa and Eurytemora affinis in the upper Chesapeake Bay showed a seasonal cycle (Fig. 5). E. affinis was abundant in the spring and declined as summer approached (Fig. 5). A. tonsa abundance was low in the spring and increased during summer (Fig. 5). Yearly average species composition for the middle and upper Bay stations showed considerable variability (Fig. 6). E. affinis was represented at Stn CB2.2 during most years and was present at Stns CB3.3C and CB4.3C only during periods of high freshwater flow (Fig. 6). At Stn CB3.3C, the large yearly averaged abundances of $E$. affinis stood out during 1996 and 1997. Despite being found only during the winter-spring period (Fig. 5), abundances of E. affinis were so high during 1996 to 1998 that the zero abundances recorded during the summer and fall had little impact on the yearly average (Fig. 6). E. affinis was also seen at Stn CB3.3C during 1990, 1991 and 1993 to 1995 (Fig. 6); all years of elevated flow or years immediately following higher flows (Fig. 1). Stations further from the major source of freshwater (Susque-

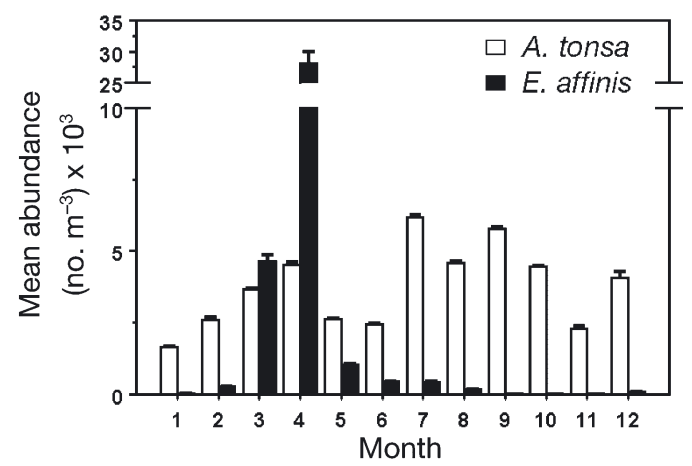

Fig. 5. Acartia tonsa and Eurytemora affinis. Mean monthly abundance (number $\mathrm{m}^{-3}$ ) in the Maryland portion of the Chesapeake Bay. Error bars represent SE of the mean 


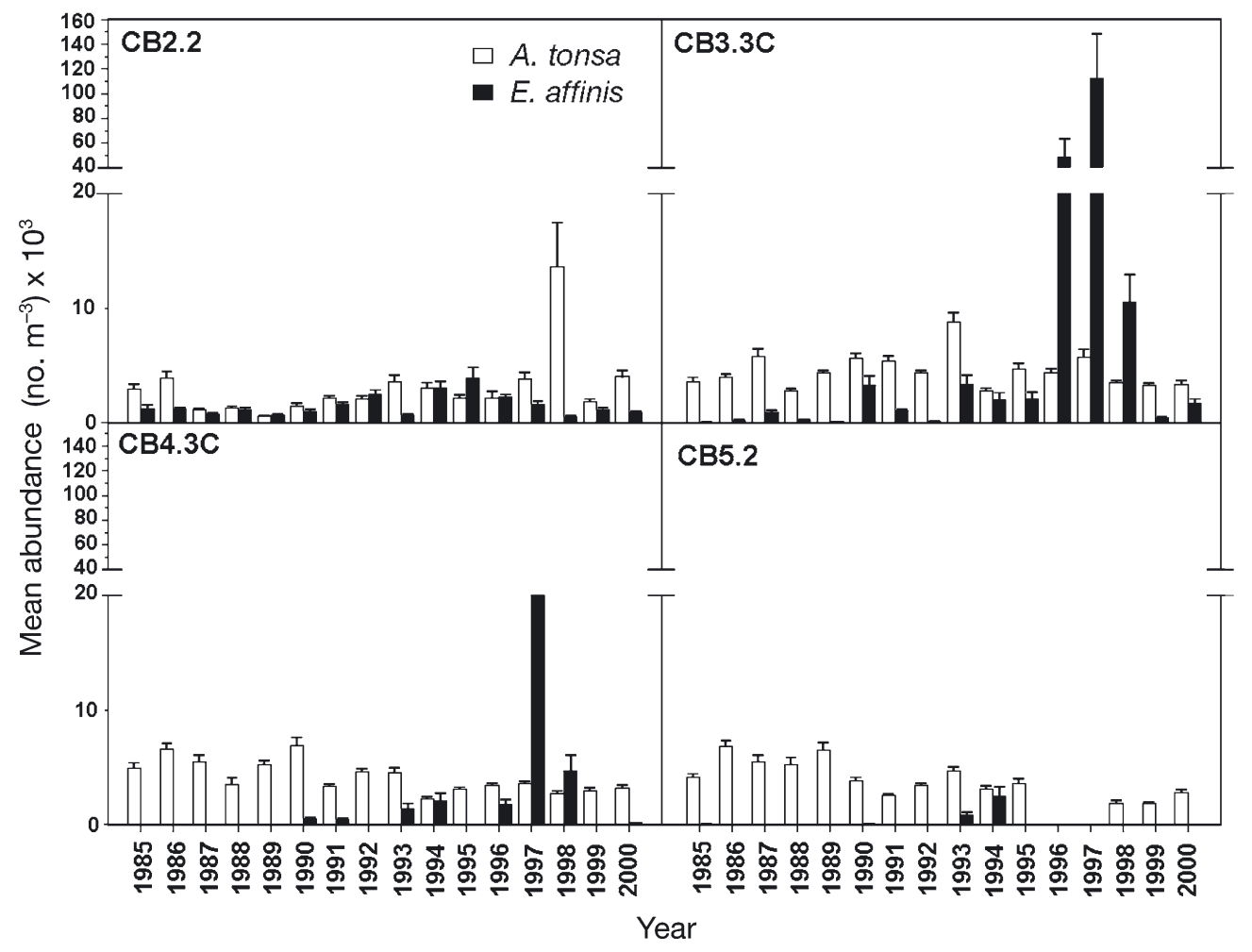

Fig. 6. Acartia tonsa and Eurytemora affinis. Mean yearly abundance in the Maryland portion of the Chesapeake Bay at stations CB2.2, CB3.3C, CB4.3C and CB5.2. Error bars represent SE

hanna River) had high E. affinis abundances during high-flow periods (Fig. 6). At Stn CB4.3C, E. affinis was found in 1993, 1994 and 1996 to 1998, but abundances were lower during the same period compared to CB3.3C (Fig. 6). However, there were high numbers of E. affinis present during 1997 (Fig. 6) suggesting a lag response following the wet year of 1996 (Fig. 1). Finally, at Stn CB5.2, low E. affinis abundances were seen during 1993 to 1994 (Fig. 6), but were not detected during the other elevated spring-flow periods (e.g. 1990 to 1991). Unfortunately, no mesozooplankton data was collected from 1996 through June of 1998 at this station, missing a potentially rare event of high E. affinis abundance.

\section{Principal component analysis}

The proportion of variance among the water-quality variables explained by the combined principal components for each station ranged from 0.71 to 0.81 (data not shown). The PCs represented major forcing functions acting in the Bay. The contribution of each individual variable can be seen in the PC loading values (Table 2). The Stn CB2.2 had 2 principal components, PC1 being primarily related to freshwater flow. Freshwater flow lowered salinity, water temperature and the Secchi depth and increased TSS and DO (by lowering the water temperature), and delivered nutrients (N, P and Si). PC 2 is primarily related to temperature and dissolved oxygen. A strong negative relationship between temperature and DO is due to the effect of temperature on oxygen solubility and also the prevalence of anoxia in the Chesapeake Bay during the summer months due to microbial activity (Roman et al. 1993). However, DO is not completely, positively correlated with increasing freshwater input, as increased flow can also lead to strong stratification and low DO values in bottom waters. TSS measurements fluctuated in the oligohaline region due to variations in physical properties and bathymetry that lead to the formation and movement of an estuarine turbidity maximum (Roman et al. 2001). Stations south of CB2.2 had similar PC results. As these areas are more highly variable in terms of salinity and tidal influence, an additional PC was extracted from the analyses. For these stations, PC1 represented flow (negative loading for these stations), temperature and DO (negative loading); PC2 represented salinity (negative loading) and Secchi depth (negative loading). PC3 is represented by the TSSTP relationship that changes seasonally in the mesohaline region or the increasing influence of ocean salinity in the polyhaline region (Table 2). 


\section{Linear mixed-effects models}

The mixed-effects models found little or no relationship between Acartia tonsa abundance and waterquality parameters for most of the stations (Table 3). However, at Stn CB2.2, A. tonsa abundance was negatively correlated to PC1 (flow) and positively correlated to primary production (Table 3 ). Flow appeared to have a negative effect on $A$. tonsa abundance, as elevated freshwater input led to lower salinities. This negative impact may also be due to competition with Eurytemora affinis which achieves high abundances during high freshwater input. Relationships between A. tonsa abundance and water-quality parameters in the mesohaline region were not found. A. tonsa showed some relationship with PC1 (temperature) in the polyhaline region, particularly in the more southern stations (Table 3). Several other variables were significant, but not consistently so across stations within regions (Table 3 ); therefore they were not likely to be related to $A$. tonsa abundance.

Residuals from the Acartia tonsa linear mixedeffects models were not serially correlated at any station in the northern Bay (Rank von Neumann test: CB2.2, $p=0.14 ;$ CB3.3C, $p=0.06$; CB4.3C, $p=0.96$; CB5.2, $p=0.42$ ). Southern Bay stations showed more seasonality in abundance, and the mixed-effects model residuals for these stations were serially correlated (Rank von Neumann test: CB6.1, p $<0.05$ CB6.4, p $<0.05$; CB7.3E, $\mathrm{p}<0.05$; CB7.4, $\mathrm{p}<0.05$ ), potentially obscuring some relationships. The model output showed that the abundance of $A$. tonsa increased in the summer and fall and declined during the winter and spring (Fig. 7). TIES data have been included in the model output (Fig. 7) during the years 1995 to 2000. TIES data appeared to match the model output for Stn CB2.2, northern Bay (Fig. 7). Spring values for $A$. tonsa abundance were predominantly below model predictions at Stn CB3.3C (Fig. 7). Two values of $A$. tonsa abundance were above the model predictions in 1997 and 1998 at Stn CB4.3C. The TIES data also provided $A$. tonsa abundance values for the period 1996 to 1998 at Stn CB5.2 (Fig. 7). TIES abundance data were consistently higher than the model output in the southern Bay stations (Fig. 7). This was expected, as the VA method for mesozooplankton enumeration underestimated the abundance at these stations (ICPRB 2000). Overall, model diagnostics showed very poor fits for the $A$. tonsa models (Table 4). The only exception was Stn CB2.2, which showed some agreement between the model and TIES data (Table 4).

The predictor variables associated with Eurytemora affinis were Mnemiopsis leidyi biovolume at Stns

Table 2. Loadings for each water-quality principal component (PC) for Chesapeake Bay stations. Temp: temperature; Secchi: secchi depth; TSS: total suspended solids; DO: dissolved oxygen; TN: total nitrogen; TP: total phosphorus

\begin{tabular}{|c|c|c|c|c|c|c|c|c|c|c|}
\hline \multirow{2}{*}{ Stn } & \multirow{2}{*}{ PC } & & & & & \multirow{2}{*}{$\begin{array}{c}\text { Variable } \\
\text { TSS }\end{array}$} & \multirow[b]{2}{*}{ DO } & \multirow[b]{2}{*}{ TN } & \multirow[b]{2}{*}{ TP } & \multirow[b]{2}{*}{$\mathrm{Si}$} \\
\hline & & Flow & Salinity & Temp & Secchi & & & & & \\
\hline \multirow[t]{2}{*}{ CB2.2 } & PC1 & 0.38 & -0.31 & -0.27 & -0.38 & 0.32 & 0.30 & 0.39 & 0.30 & 0.32 \\
\hline & PC2 & 0.09 & 0.30 & -0.54 & 0.23 & -0.36 & 0.50 & 0.15 & -0.39 & 0.06 \\
\hline \multirow[t]{3}{*}{ CB3.3C } & PC1 & -0.45 & 0.28 & 0.46 & 0.06 & -0.34 & -0.41 & -0.40 & 0.13 & 0.20 \\
\hline & PC2 & 0.10 & -0.39 & 0.23 & -0.50 & 0.13 & -0.21 & 0.28 & 0.44 & 0.46 \\
\hline & PC3 & -0.16 & 0.42 & -0.06 & 0.14 & 0.59 & 0.23 & -0.11 & 0.60 & 0.02 \\
\hline \multirow[t]{3}{*}{ CB4.3C } & PC1 & -0.39 & 0.16 & 0.47 & -0.08 & -0.30 & -0.45 & -0.31 & 0.31 & 0.32 \\
\hline & PC2 & 0.23 & -0.55 & 0.09 & -0.46 & 0.02 & -0.12 & 0.44 & 0.24 & 0.38 \\
\hline & PC3 & -0.14 & 0.26 & -0.14 & -0.12 & 0.69 & 0.19 & -0.10 & 0.59 & 0.12 \\
\hline \multirow[t]{3}{*}{ CB5.2 } & PC1 & -0.40 & 0.12 & 0.48 & -0.15 & -0.27 & -0.48 & -0.22 & 0.25 & 0.39 \\
\hline & PC2 & 0.21 & -0.54 & 0.06 & -0.48 & 0.11 & -0.08 & 0.54 & 0.23 & 0.25 \\
\hline & PC3 & -0.21 & 0.34 & -0.11 & -0.10 & 0.66 & 0.13 & -0.02 & 0.61 & 0.003 \\
\hline \multirow[t]{3}{*}{ CB6.1 } & PC1 & -0.38 & 0.13 & 0.46 & -0.21 & 0.19 & -0.46 & 0.03 & 0.42 & 0.40 \\
\hline & PC2 & 0.31 & -0.59 & -0.04 & -0.35 & 0.22 & 0.09 & 0.57 & 0.19 & 0.11 \\
\hline & PC3 & 0.13 & -0.22 & 0.22 & 0.40 & -0.68 & -0.26 & 0.26 & -0.15 & 0.31 \\
\hline \multirow[t]{3}{*}{ CB6.4 } & PC1 & -0.39 & 0.17 & 0.47 & -0.09 & 0.13 & -0.48 & 0.07 & 0.37 & 0.44 \\
\hline & PC2 & 0.24 & -0.43 & -0.09 & -0.50 & 0.50 & 0.11 & 0.42 & 0.24 & 0.07 \\
\hline & PC3 & 0.24 & -0.42 & 0.21 & 0.46 & -0.43 & -0.13 & 0.54 & 0.02 & 0.12 \\
\hline \multirow[t]{3}{*}{ CB7.3E } & PC1 & -0.38 & 0.20 & 0.48 & -0.06 & 0.14 & -0.48 & 0.09 & 0.37 & 0.42 \\
\hline & PC2 & 0.26 & -0.34 & -0.10 & -0.48 & 0.48 & 0.15 & 0.48 & 0.30 & 0.07 \\
\hline & PC3 & 0.23 & -0.58 & 0.23 & 0.34 & -0.43 & -0.21 & 0.40 & -0.13 & 0.21 \\
\hline \multirow[t]{3}{*}{ CB7.4 } & PC1 & -0.44 & 0.18 & 0.53 & 0.20 & -0.19 & -0.53 & 0.003 & 0.14 & 0.34 \\
\hline & PC2 & 0.10 & -0.22 & 0.06 & -0.39 & 0.44 & -0.03 & 0.47 & 0.50 & 0.34 \\
\hline & PC3 & 0.24 & -0.82 & 0.21 & 0.07 & -0.17 & -0.14 & -0.003 & -0.37 & 0.20 \\
\hline
\end{tabular}


Table 3. Regression coefficients (coef.) and $t$-values (Student's $t$-test) for linear mixed-effects model of Acartia tonsa abundance at the Chesapeake Bay stations. * Significance at the $\alpha=0.05$ (Bonferroni corrected $\alpha=0.006$ ) level for the northern stations and significance at the $\alpha=0.05$ (Bonferroni corrected $\alpha=0.0125$ ) level for the southern stations. Prim prod: primary production; phyto: phytoplankton; microzoo: microzooplankton; PC: principal component

\begin{tabular}{|c|c|c|c|c|c|c|c|c|c|c|}
\hline \multirow[t]{2}{*}{ Stn } & & \multirow[b]{2}{*}{ Intercept } & \multirow[b]{2}{*}{ Mnemiopsis } & \multirow[b]{2}{*}{ Chl a } & \multirow[b]{2}{*}{ Prim prod } & \multirow{2}{*}{$\begin{array}{c}\text { Variable } \\
\text { Phyto }\end{array}$} & \multirow[b]{2}{*}{ Microzoo } & \multirow[b]{2}{*}{ PC 1} & \multirow[b]{2}{*}{ PC 2} & \multirow[b]{2}{*}{ PC 3} \\
\hline & & & & & & & & & & \\
\hline \multirow[t]{4}{*}{ CB2.2 } & $\mathrm{df}$ & 136 & 136 & 136 & 136 & 136 & 136 & 136 & 136 & 136 \\
\hline & Coef. & 3.81 & -0.15 & -0.19 & 0.06 & -0.19 & & -0.39 & -0.15 & \\
\hline & (t-value) & $(1.84)$ & $(-1.55)$ & $(-0.89)$ & $(1.03)$ & $(-0.64)$ & & $(-6.76)$ & $(-1.74)$ & \\
\hline & p-value & 0.07 & 0.12 & 0.37 & 0.30 & 0.52 & & $<0.05^{*}$ & 0.08 & \\
\hline \multirow[t]{4}{*}{ CB3.3C } & $\mathrm{df}$ & 132 & 132 & 132 & 132 & 132 & 132 & 132 & 132 & 132 \\
\hline & Coef. & 3.86 & -0.07 & -0.23 & -0.002 & -0.03 & 0.10 & 0.003 & 0.05 & 0.10 \\
\hline & (t-value) & $(2.19)$ & $(-1.76)$ & $(-1.62)$ & $(-0.21)$ & $(-0.10)$ & $(2.26)$ & $(0.12)$ & $(1.98)$ & $(2.94)$ \\
\hline & p-value & $<0.05$ & 0.08 & 0.11 & 0.83 & 0.92 & $<0.05$ & 0.90 & 0.05 & $<0.05^{*}$ \\
\hline \multirow[t]{4}{*}{ CB4.3C } & $\mathrm{df}$ & 139 & 139 & 139 & 139 & 139 & 139 & 139 & 139 & 139 \\
\hline & Coef. & 2.48 & -0.06 & -0.35 & 0.01 & 0.41 & 0.01 & -0.01 & 0.03 & -0.06 \\
\hline & (t-value) & $(0.31)$ & $(-1.15)$ & $(-1.31)$ & $(0.60)$ & $(0.16)$ & $(0.13)$ & $(-0.30)$ & $(0.76)$ & $(-1.32)$ \\
\hline & p-value & 0.76 & 0.25 & 0.19 & 0.55 & 0.88 & 0.90 & 0.77 & 0.45 & 0.19 \\
\hline \multirow[t]{4}{*}{ CB5.2 } & df & 114 & 114 & 114 & 114 & 114 & 114 & 114 & 114 & 114 \\
\hline & Coef. & 6.06 & -0.14 & 0.04 & 0.03 & -0.50 & -0.16 & -0.02 & 0.02 & 0.07 \\
\hline & (t-value) & $(2.58)$ & $(-2.34)$ & $(0.26)$ & $(2.03)$ & $(-1.11)$ & $(-1.94)$ & $(-0.37)$ & $(0.47)$ & $(1.38)$ \\
\hline & p-value & $<0.05$ & $<0.05$ & 0.80 & $<0.05$ & 0.27 & 0.05 & 0.71 & 0.64 & 0.17 \\
\hline \multirow[t]{4}{*}{ CB6.1 } & $\mathrm{df}$ & 160 & & & & & 160 & 160 & 160 & 160 \\
\hline & Coef. & 1.96 & & & & & 0.61 & 0.09 & -0.18 & 0.10 \\
\hline & (t-value) & $(4.18)$ & & & & & $(1.26)$ & $(1.23)$ & $(-2.01)$ & $(1.11)$ \\
\hline & p-value & $<0.05^{*}$ & & & & & 0.21 & 0.22 & 0.05 & 0.27 \\
\hline \multirow[t]{4}{*}{ CB6.4 } & $\mathrm{df}$ & 158 & & & & & 158 & 158 & 158 & 158 \\
\hline & Coef. & 2.21 & & & & & 0.28 & 0.19 & -0.19 & 0.17 \\
\hline & (t-value) & $(5.26)$ & & & & & $(0.91)$ & $(3.16)$ & $(-2.55)$ & $(2.07)$ \\
\hline & p-value & $<0.05^{*}$ & & & & & 0.36 & $<0.05^{*}$ & $<0.05^{*}$ & $<0.05$ \\
\hline \multirow[t]{4}{*}{ CB7.3E } & $\mathrm{df}$ & 156 & & & & & 156 & 156 & 156 & 156 \\
\hline & Coef. & 3.22 & & & & & -0.45 & 0.34 & 0.01 & 0.26 \\
\hline & (t-value) & (9.39) & & & & & $(-2.07)$ & $(5.84)$ & $(0.13)$ & (3.19) \\
\hline & p-value & $<0.05^{*}$ & & & & & $<0.05$ & $<0.05^{*}$ & 0.89 & $<0.05^{*}$ \\
\hline \multirow[t]{4}{*}{ CB7.4 } & $\mathrm{df}$ & 156 & & & & & 156 & 156 & 156 & 156 \\
\hline & Coef. & 1.80 & & & & & 0.29 & 0.30 & 0.12 & 0.01 \\
\hline & (t-value) & $(5.79)$ & & & & & $(1.31)$ & $(4.62)$ & $(1.87)$ & $(0.10)$ \\
\hline & p-value & $<0.05^{*}$ & & & & & 0.19 & $<0.05^{*}$ & 0.06 & 0.92 \\
\hline
\end{tabular}

CB2.2 and CB3.3C, and PC 2 (low salinity) at Stns CB3.3C and CB4.3C (Table 5). At Stn CB5.2, there were no significant relationships between $E$. affinis and any of the water-quality parameters. Models were not significant for $E$. affinis abundance at any of the southern Bay stations (data not shown), as E. affinis is primarily restricted to upper Bay waters and lower salinities. Residuals from the E. affinis linear mixedeffects models were serially correlated at several stations (Rank von Neumann test: CB2.2, p < 0.05; CB3.3C, p < 0.05; CB4.3C, p=0.09; CB5.2, p=0.05). It was not possible to remove the autocorrelation present in the E. affinis data by grouping the data. However, serial correlation was reduced when compared to a classic linear regression model.
Table 4. Linear mixed-effects model diagnostics for Acartia tonsa. RMSE (root mean square error); $\mathrm{r}^{2}$, slope and intercept from linear regression between model predicted data and mesozooplankton abundance from TIES (Trophic Interaction in Estuarine Sysems) cruises

\begin{tabular}{|lclrc|}
\hline Stn & RMSE & $\mathrm{r}^{2}$ & Slope & Intercept \\
\hline CB2.2 & 1.03 & 0.40 & 0.55 & 1.34 \\
CB3.3C & 1.25 & 0.002 & -0.13 & 3.60 \\
CB4.3C & 1.36 & 0.03 & -0.59 & 5.17 \\
CB5.2 & 1.68 & 0.17 & -0.58 & 5.17 \\
CB6.1 & 1.05 & 0.18 & 0.32 & 2.63 \\
CB6.4 & 1.19 & 0.10 & 0.37 & 2.55 \\
CB7.3E & 1.06 & 0.09 & 0.30 & 2.67 \\
CB7.4 & 1.42 & 0.003 & 0.06 & 3.29 \\
\hline
\end{tabular}


The model output emphasized the peak in Eurytemora affinis abundance during the spring in the northern Bay (Fig. 8). Abundances were high in the spring and low or zero during the summer and fall. In general, the TIES data appeared to match the model output fairly well; however some differences can be noted. High abundances of $E$. affinis were seen during late 1996, the extremely wet year (Fig. 1), at all stations (Fig. 8). The model predicted low or zero abundances for this period. TIES data also showed high E. affinis abundance at Stn CB5.2 during the 1996 to 1998 period (Fig. 8). The models agreed with E. affinis TIES values quite well in the mesohaline region and showed little agreement for the southern Chesapeake Bay stations (Table 6). Ctenophore abundance also seemed to be related to freshwater input. Biovolume of Mnemiopsis leidyi was elevated in wet years (Fig. 9). The wet periods 1993, 1994 and 1996 to 1998 had higher M. leidyi levels at the mesohaline stations.

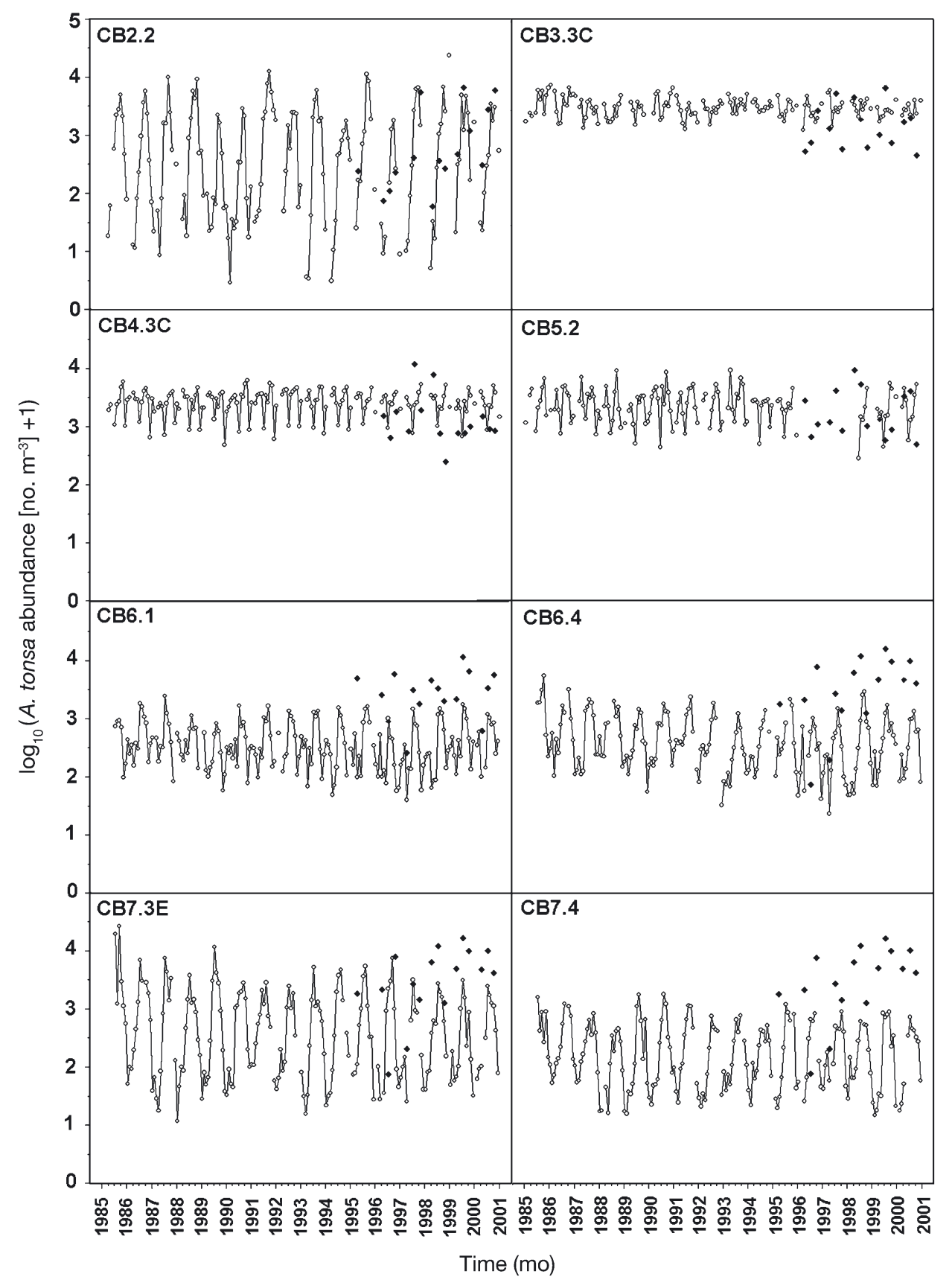

Fig. 7. Acartia tonsa. $\log _{10}(x+1)$ transformed abundance (number $\mathrm{m}^{-3}$ ) fitted by linear mixed-effects models for the Chesapeake Bay Program sampling stations ( $($ ) and abundance from TIES (Trophic Interaction in Estuarine Systems) data (•) 
Table 5. Regression coefficients and $t$-values for linear mixed-effects model of Eurytemora affinis abundance at the northern Chesapeake Bay stations. *Significance at the $\alpha=0.05$ (Bonferroni corrected $\alpha=0.006$ ) level. For abbreviations see Table 3

\begin{tabular}{|c|c|c|c|c|c|c|c|c|c|c|}
\hline \multirow[t]{2}{*}{ Stn } & & \multirow[b]{2}{*}{ Intercept } & \multirow[b]{2}{*}{ Mnemiopsis } & \multirow[b]{2}{*}{ Chl a } & \multirow{2}{*}{$\begin{array}{l}\text { Var } \\
\text { Prim prod }\end{array}$} & \multirow{2}{*}{$\begin{array}{l}\text { iable - } \\
\text { Phyto }\end{array}$} & \multirow[b]{2}{*}{ Microzoo } & \multirow[b]{2}{*}{ PC 1} & \multirow[b]{2}{*}{ PC 2} & \multirow[b]{2}{*}{ PC 3} \\
\hline & & & & & & & & & & \\
\hline \multirow[t]{4}{*}{ CB2.2 } & $\mathrm{df}$ & 136 & 136 & 136 & 136 & 136 & 136 & 136 & 136 & 136 \\
\hline & Coef. & -4.95 & -0.51 & 0.17 & 0.01 & 0.97 & & 0.09 & -0.04 & \\
\hline & ( $t$-value) & $(-2.40)$ & $(-4.94)$ & $(0.78)$ & $(0.15)$ & $(3.28)$ & & $(1.42)$ & $(-0.37)$ & \\
\hline & $\mathrm{p}$-value & $<0.05$ & $<0.05^{*}$ & 0.44 & 0.88 & $<0.05^{*}$ & & 0.16 & 0.71 & \\
\hline \multirow[t]{4}{*}{ CB3.3C } & $\mathrm{df}$ & 132 & 132 & 132 & 132 & 132 & 132 & 132 & 132 & 132 \\
\hline & Coef. & -4.14 & -0.20 & -0.27 & -0.02 & 1.03 & 0.15 & 0.12 & 0.27 & -0.04 \\
\hline & ( $t$-value) & $(-1.71)$ & $(-3.12)$ & $(-1.30)$ & $(-1.22)$ & $(2.25)$ & $(2.41)$ & $(1.50)$ & $(4.83)$ & $(-0.76)$ \\
\hline & p-value & 0.09 & $<0.05^{*}$ & 0.19 & 0.22 & $<0.05$ & $<0.05$ & 0.14 & $<0.05^{*}$ & 0.45 \\
\hline \multirow[t]{4}{*}{ CB4.3C } & $\mathrm{df}$ & 139 & 139 & 139 & 139 & 139 & 139 & 139 & 139 & 139 \\
\hline & Coef. & -0.91 & -0.05 & -0.05 & 0.02 & 0.46 & 0.04 & 0.15 & 0.20 & -0.04 \\
\hline & ( $t$-value) & $(-0.09)$ & $(-0.76)$ & $(-0.14)$ & $(0.79)$ & $(0.14)$ & $(0.67)$ & $(1.83)$ & $(4.45)$ & $(-0.70)$ \\
\hline & p-value & 0.93 & 0.44 & 0.89 & 0.43 & 0.89 & 0.50 & 0.07 & $<0.05^{*}$ & 0.48 \\
\hline \multirow[t]{4}{*}{ CB5.2 } & $\mathrm{df}$ & 114 & 114 & 114 & 114 & 114 & 114 & 114 & 114 & 114 \\
\hline & Coef. & -0.26 & -0.12 & 0.06 & 0.01 & 0.11 & 0.02 & -0.08 & 0.12 & -0.09 \\
\hline & ( $t$-value) & $(-0.09)$ & $(-1.59)$ & $(0.32)$ & $(0.55)$ & $(0.22)$ & $(0.21)$ & $(-1.27)$ & (2.19) & $(-1.47)$ \\
\hline & p-value & 0.92 & 0.11 & 0.75 & 0.58 & 0.83 & 0.84 & 0.20 & $<0.05$ & 0.14 \\
\hline
\end{tabular}

\section{DISCUSSION}

Acartia tonsa and Eurytemora affinis showed no apparent trend in abundance over the 16 yr monitoring period. The slight downward trend seen at Stn CB5.2 is likely biased by the absence of data during 1996 to 1998 when sampling was not conducted. While each species showed spatial, seasonal and interannual variability, the overall abundance of both species appears to have remained unchanged over the $16 \mathrm{yr}$ timeseries. The lack of trends in each species may be due to the short length of the time-series. Harding \& Perry (1997) were able to demonstrate a long-term increase in phytoplankton biomass in the Chesapeake Bay

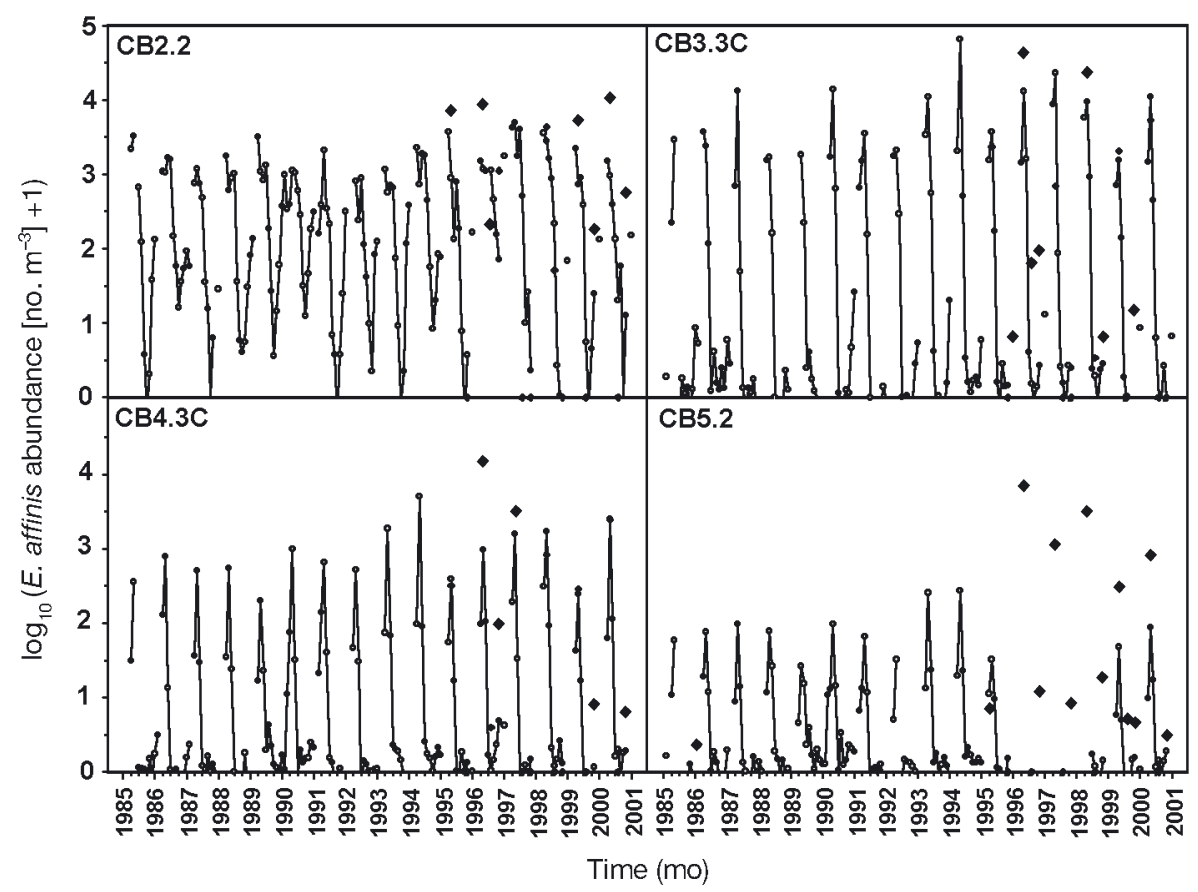

Fig. 8. Eurytemora affinis. $\log _{10}(x+1)$ transformed abundance (number $\mathrm{m}^{-3}$ ) fitted by linear mixed-effects models for the northern Bay stations ( $($ ) and abundance from TIES data $(\bullet)$ 
using a monthly data set of approximately $50 \mathrm{yr}$. The $16 \mathrm{yr}$ CBP time-series may not be long enough to show any recent changes in abundance. There was no long-term trend in water temperature. However, a long-term decline in salinity was found during the study period, highlighting the influence of the recent wet period in Chesapeake Bay.

The overall influence of freshwater input on Acartia tonsa and Eurytemora affinis in Chesapeake Bay can be viewed as a combination of top-down and bottom-up effects that are spatially dependent (Fig. 10). Freshwater input appeared to have little impact on the abundance of $A$. tonsa, as this copepod species did not respond to increasing freshwater input except in the oligohaline region of the Bay (Fig. 7, Stn CB2.2). This

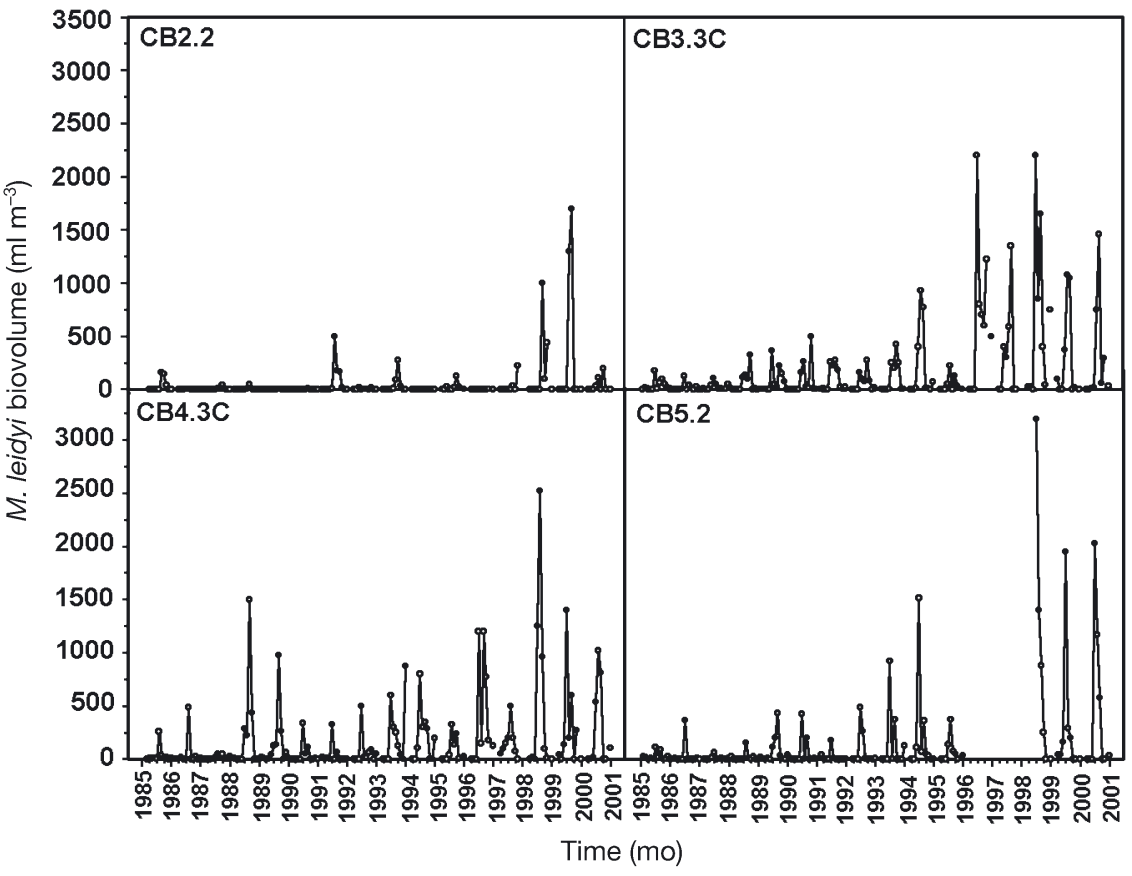

Fig. 9. Mnemiopsis leidyi. Biovolume $\left(\mathrm{ml} \mathrm{m}^{-3}\right)$ in the oligohaline and mesohaline Chesapeake Bay at Stns CB2.2, CB3.3C, CB4.3C and CB5.2 reduction was apparently due to a drop in salinity and temperature during the winterspring period and possible removal (flushing out) of the copepod from the region (Fig. 10, mechanism 1). Food limitation due to lower phytoplankton abundance or chl a does not appear to be a likely factor limiting populations of A. tonsa in this region (Table 3), as no food-related variables were significant in the model (Fig. 10, mechanisms 2 and 3). White \& Roman (1992) found that the best predictor of $A$. tonsa egg production in Chesapeake Bay was temperature, not chl a concentration. This agrees in part with our findings as A. tonsa populations decreased with lowered salinities and temperatures and were correlated with temperature at the southern Bay stations (Table 3). Freshwater

Table 6. Linear mixed-effects model diagnostics for Eurytemora affinis. RMSE (root mean square error); $\mathrm{r}^{2}$, slope and intercept from linear regression between model predicted data and mesozooplankton abundance from TIES (Trophic Interaction in Estuarine Systems) cruises

\begin{tabular}{|lcccc|}
\hline Stn & RMSE & $\mathrm{r}^{2}$ & Slope & Intercept \\
\hline CB2.2 & 1.10 & 0.55 & 1.06 & -0.07 \\
CB3.3C & 0.76 & 0.83 & 0.84 & 0.43 \\
CB4.3C & 0.53 & 0.89 & 1.00 & 0.22 \\
CB5.2 & 0.66 & 0.66 & 1.07 & 0.29 \\
CB6.1 & 1.85 & 0.37 & 3.22 & 1.09 \\
CB6.4 & 2.24 & 0.09 & 4.29 & 1.73 \\
CB7.3E & 2.22 & 0.21 & 4.92 & 1.53 \\
CB7.4 & 2.28 & 0.28 & 13.08 & 0.78 \\
& & & & \\
\hline
\end{tabular}

input can cause greater stratification of DO. This stratification can lead to low DO levels in bottom waters as temperatures increase and has been shown to cause egg mortality in A. tonsa (Roman et al. 1993). Thus, it may depend on the location of $A$. tonsa populations in the water column as to whether lowered DO has an

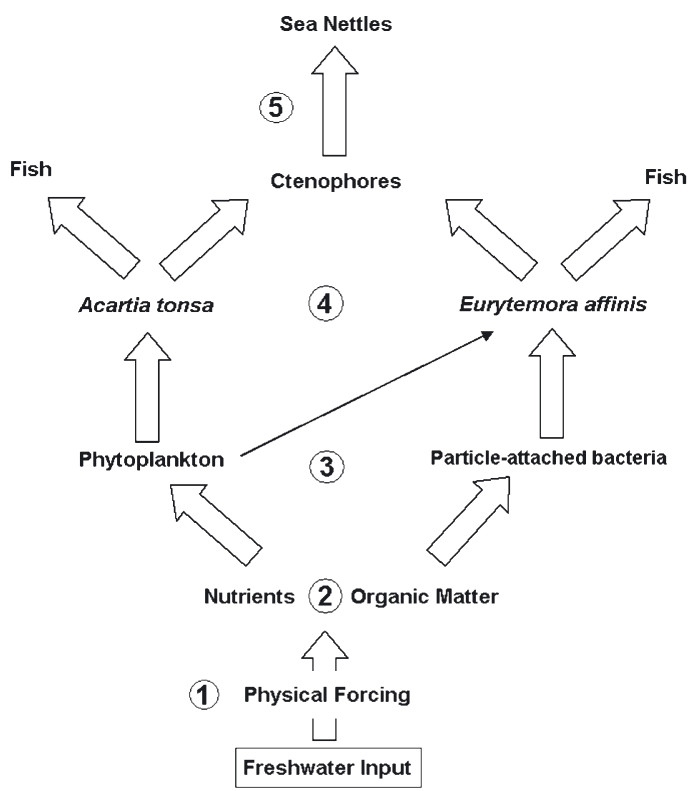

Fig. 10. Conceptual model of a simple Chesapeake Bay food web. Arrows indicate flow of energy and numbers indicate mechanisms (described in the text) 
impact. The use of oblique tow data precludes knowledge of the exact location of sampled mesozooplankton in the water column. Overall, A. tonsa experiences relatively little year-to-year variation in average monthly abundance in the mesohaline portion of the northern Chesapeake Bay and only seasonal variation in the southern Bay.

Higher than average spring flows tend to be correlated with high Eurytemora affinis abundances and persistence of $E$. affinis populations for longer periods of time (Fig. 6). High spring flows also result in E. affinis displacement of $E$. affinis estuary southwards within the (Fig. 8; Fig. 10, mechanism 1); this can be extensive, as was seen in 1997 (Fig. 6). High flows late in the year can lead to $E$. affinis populations persisting into the fall, when they are not normally found (Fig. 8, Stn CB3.3C). Furthermore, the high freshwater input seen in the fall of 1996 may have resulted in higher populations in the spring of 1997 (Fig. 6). The large increase in E. affinis abundance seen during 1997 may be due to the hatching of diapause eggs (Hairston 1996). Fall flow appears to be important because 1998 had extremely high monthly flows in the spring and below average flows during the fall months. As a result, large abundances of E. affinis were not seen during the fall of 1998 or the spring of 1999 (Fig. 6, Stns CB3.3C and CB4.3C). The increase in E. affinis abundance during high freshwater input may be linked to an increase in preferred habitat: low salinity, low temperature and increased turbidity (Fig. 10, mechanism 1; Bradley 1991). The increase may also be linked to an increase in the levels of organic matter (Fig. 10, mechanism 2) that leads to high particle-attached bacteria levels, particularly in the estuarine turbidity maximum region (Fig. 10, mechanism 3; Crump et al. 1998). The increase in $E$. affinis abundance would have a positive impact on anadromous fish larvae, such as Morone saxatilis (striped bass) and M. americana (white perch) that use the northern Bay and its tributaries as a larval nursery ground (Fig. 10, mechanism 4). The larvae of striped bass and white perch are normally located within $10 \mathrm{~km}$ of the estuarine turbidity maximum (North \& Houde 2001) and E. affinis is an important food source in this region. One study estimated that 58,53 and $99 \%$ of the prey organisms M. saxatilis consumed in the Choptank River, Maryland during 1983, 1984 and 1985 respectively were E. affinis (Uphoff 1989).

Acartia tonsa and Eurytemora affinis inhabit similar regions of the northern Chesapeake Bay and are dominant at different times of the year (Bradley 1991). A zone of seasonal succession exists (between salinities of 2 to 18 ) for the 2 species in which $E$. affinis is dominant in the winter-spring and $A$. tonsa in the summerfall (Bradley 1991). It has been hypothesized that salinity and temperature are controlling seasonal succession between the 2 species (Bradley 1991, Kimmel
\& Bradley 2001). Bradley (1991) reported that E. affinis was abundant at a salinity of 12 at $0^{\circ} \mathrm{C}$ but not at a salinity of 8 at $25^{\circ} \mathrm{C}_{i}$ conversely, $\mathrm{A}$. tonsa was abundant at a salinity of 8 at $25^{\circ} \mathrm{C}$ but not at a salinity of 11 at $1^{\circ} \mathrm{C}$. There is no evidence for competition for food resources; however, there is evidence that $A$. tonsa may feed on E. affinis nauplii (A. Kirby \& M. R. Roman unpubl. data). Ambler et al. (1985) described a similar scenario during low and high flow years in the San Francisco Bay, California: during high flows, the range of the euryhaline copepod E. affinis was expanded as the estuary became fresher seaward of the estuarine turbidity maximum; conversely, during low flows, the distribution of $E$. affinis was restricted to the upper reaches of the Bay and the other dominant copepod, A. tonsa, was found further up the estuary.

The influence of gelatinous predators on mesozooplankton populations may be modulated by freshwater flow in the Chesapeake Bay (Fig. 10, mechanism 4). Mnemiopsis leidyi biovolume appears to be higher during periods of increased freshwater input (Fig. 9). High ctenophore biovolume was seen in 1996 and 1998, both years of elevated spring flow (Fig. 9). This may be due to lower levels of the main predator of $M$. leidyi, the sea nettle Chrysaora quinquecirrha (Fig. 10, mechanism 5). Cargo \& King (1990) found that freshwater input in spring resulted in decreased summer C. quinquecirrha abundances. Thus, high flow years tend to have higher $M$. leidyi populations as $C$. quinquecirrha is excluded from the mesohaline Bay due to low salinities. This may explain why A. tonsa populations do not increase in the mesohaline Chesapeake Bay during high-flow years. Despite the fact that high flow can stimulate primary production in the mesohaline Bay region (Harding 1994), thereby benefiting Acartia tonsa, it may also cause higher $M$. leidyi biovolumes that reduce $A$. tonsa populations (Fig. 10, mechanisms 3 and 4). A decline in A. tonsa populations has a negative impact on fish, such as Bay anchovy (Anchoa mitchelli) populations which rely on $A$. tonsa nauplii as an important prey item during the summer months (Rilling \& Houde 1999, Jung 2002). Eurytemora affinis seems to be limited by salinity and temperature during the fall-summer period in the mesohaline Bay but may achieve high abundance in this region during winter-spring freshwater input (Fig. 6). However, more $M$. leidyi persist during these flow events and prey on E. affinis. E. affinis reaches these high abundance values early in the spring and at low temperatures possibly avoiding the highest levels of ctenophore abundance, which occur later in the year. If more winter samples were collected, it may be possible to see the effects of mild/wet winters on E. affinis abundances. The combination of increasing salinity, temperature and ctenophore abundances would likely cause $E$. affinis populations to decline in the summer during high-flow years. 
Acknowledgements. The authors thank E. Russek-Cohen for advice on statistical analysis; T. Kimmel, S. Lloyd, M. Reaugh and X. Zhang for helpful comments on the manuscript. Although the research described in this article has been funded wholly or in part by the United States Environmental Protection Agency through cooperative agreement R82867701 to Atlantic Coast Estuaries Indicators Consortium, it has not been subjected to the Agency's required peer and policy review and therefore does not necessarily reflect the views of the Agency and no official endorsement should be inferred. The authors also thank The Sloan Foundation, Census of Marine Life Program 2001-3-8, NOAA Coast Ocean Program NA170P2656 and the National Science Foundation LMER-TIES Program DEB 94-12113. Monitoring Data was provided by the EPA Chesapeake Bay Program.

\section{LITERATURE CITED}

Aleem AA (1972) Effect of river outflow management on marine life. Mar Biol 15:200-208

Ambler JW, Cloern JE, Hutchinson A (1985) Seasonal cycles of zooplankton from San Francisco Bay. Hydrobiologia 129:177-197

Bradley BP (1991) Distribution of copepods in coastal zone waters: seasonal succession in Chesapeake Bay. Bull Plankton Soc Jpn Spec Vol 129-131

Brownlee DC, Jacobs F (1987) Mesozooplankton and microzooplankton in the Chesapeake Bay. In: Majumdar SK, Hall LW, Austin HW (eds) Contaminant problems and management of living Chesapeake Bay resources, Vol 527. The Pennsylvania Academy of Science, Philadelphia, PA, p 217-269

Bue CD (1968) Monthly surface-water inflow to Chesapeake Bay: US Geological Survey Open-File Report, United States Geological Survey, Arlington, VA

Cargo DG, King DR (1990) Forecasting the abundance of the sea nettle Chrysaora quinquecirrha, in the Chesapeake Bay. Estuaries 13:486-491

CBP (Chesapeake Bay Program) (2000) Guide to living resources data. Chesapeake Bay Program. Annapolis, MD

Crump BC, Baross JA, Simenstad CA (1998) Dominance of particle-attached bacteria in the Columbia River estuary, USA. Aquat Microb Ecol 14:7-18

Flint RW (1985) Long-term estuarine variability and associated biological response. Estuaries 8:158-169

Hairston NG (1996) Zooplankton egg banks as biotic reservoirs in changing environments. Limnol Oceanogr 41: 1087-1092

Harding LW (1994) Long-term trends in the distribution of phytoplankton in Chesapeake Bay: roles of light, nutrients and streamflow. Mar Ecol Prog Ser 104:267-291

Harding LW, Perry ES (1997) Long-term increase of phytoplankton biomass in Chesapeake Bay, 1950-1994. Mar Ecol Prog Ser 157:39-52

ICPRB (Interstate Commission on the Potomac River Basin) (2000) The 1998-1999 Split-sample study for the Chesapeake Bay program phytoplankton, microzooplankton and mesozooplankton monitoring components. ICPRB Report 00-3, Rockville, MD

Jassby AD, Powell TM (1994) Hydrodynamic influences on interannual chlorophyll variability in an estuary: upper San Francisco Bay-Delta (California: USA). Estuar Coast Shelf Sci 39:595-618

Editorial responsibility: Otto Kinne (Editor),

Oldendorf/Luhe, Germany
Jung S (2002) Fish community structure and the spatial and temporal variability in recruitment and biomass production in Chesapeake Bay. PhD thesis, University of Maryland, College Park, MD

Kimmel DG, Bradley BP (2001) Specific protein responses in the calanoid copepod Eurytemora affinis (Poppe, 1880) to salinity and temperature variation. J Exp Mar Biol Ecol 266:135-149

Kimmerer WJ (2002) Effects of freshwater flow on abundance of estuarine organisms: physical effects or trophic linkages? Mar Ecol Prog Ser 243:39-55

Livingston R, Niu X, Lewis F III, Woodsum G (1997) Freshwater input to a gulf estuary: long-term control of trophic organization. Ecol Appl 7:277-299

Mallin MA, Paerl HW, Rudek J, Bates PW (1993) Regulation of estuarine primary production by watershed rainfall and river flow. Mar Ecol Prog Ser 93:199-203

Malone TC, Crocker LH, Pike SE, Wendler BW (1988) Influences of river flow on the dynamics of phytoplankton production in a partially stratified estuary. Mar Ecol Prog Ser 48:235-249

Montagna PA, Kalke RD (1992) The effect of freshwater inflow on meiofaunal and macrofaunal populations in the Guadalupe and Nueces estuaries, Texas. Estuaries 15: 307-326

North EW, Houde ED (2001) Retention of white perch and striped bass larvae: biological-physical interactions in Chesapeake Bay estuarine turbidity maximum. Estuaries 24:756-769

Pinheiro JC, Bates DM (2000) Mixed-effects models in S and S-PLUS. Springer-Verlag, New York, NY

Rilling GC, Houde ED (1999) Regional and temporal variability in distribution and abundance of bay anchovy (Anchoa mitchilli) eggs, larvae, and adult biomass in the Chesapeake Bay. Estuaries 22:1096-1109

Roman MR, Gauzens AL, Rhinehart WK, White JR (1993) Effects of low oxygen waters on Chesapeake Bay zooplankton. Limnol Oceanogr 38:1603-1614

Roman MR, Holliday DV, Sanford LP (2001) Temporal and spatial patterns of zooplankton in the Chesapeake Bay turbidity maximum. Mar Ecol Prog Ser 213:215-227

Schubel JR, Pritchard DW (1986) Responses of upper Chesapeake Bay to variations in discharge of the Susquehanna River. Estuaries 9:236-249

Sieburth JM, Smetacek V, Lenz J (1978) Pelagic ecosystem structure: heterotrophic compartments of the plankton and their relationship to plankton size fractions. Limnol Oceanogr 23:1256-1263

Sokal RR, Rohlf FJ (1995) Biometry: the principles and practice of statistics in biological research. WH Freeman, New York

Uphoff JH (1989) Environmental effects on survival of eggs, larvae and juveniles of striped bass in the Choptank River, Maryland. Trans Am Fish Soc 118:251-263

Venables WN, Ripley BD (1999) Modern applied statistics with S-PLUS. Springer-Verlag, New York

White JR, Roman MR (1992) Seasonal study of grazing by metazoan zooplankton in the mesohaline Chesapeake Bay. Mar Ecol Prog Ser 86:251-261

Workshop on Trophic Change in Chesapeake Bay Open Water Habitat (1998) A workshop to evaluate and interpret recent trends. Scientific and Technical Advisory Committee (STAC) of the Chesapeake Bay Program. Solomons, MD

Submitted: February 18, 2003; Accepted: August 30, 2003

Proofs received from author(s): February 10, 2004 